JURNAL RISET REKAYASA ELEKTRO

Vol.3, No.2, Desember 2021, Hal. 127 140

P-ISSN: 2685 - 4341

E-ISSN: 2685 - 5313

\title{
Implementasi Internet Of Things Untuk Monitoring Kualitas Air Secara Realtime Pada Utilities PT.Kilang Pertamina Internasional Cilacap Berbasis Mikrokontroler Nodemcu Esp 32
}

Rudi Khaerudin ${ }^{1}$, Itmi Hidayat Kurniawan ${ }^{2}$

Program Studi Teknik Elektro, Universitas Muhammadiyah Purwokerto

Fakultas Teknik dan Sains, Universitas Muhammadiyah Purwokerto

\section{Informasi Makalah}

Dikirim, 20 Agustus 2021

Direvisi, 27 Agustus 2021

Diterima, 27 Agustus 2021

\section{Kata Kunci:}

Internet of things, NodeMcu ESP 32,

Cloud Firebase,

Kualitas air

\begin{abstract}
INTISARI
Pada sektor industri pengilangan minyak kebutuhan air sangat dibutuhkan sebagai air umpan pada ketel uap. Pada sektor ini air memiliki berbagai macam fungsi diantaranya untuk diubah menjadi uap sebagai pemutar turbin dalam pembangkitan energi listrik. Beberapa parameter yang penting terhadap untuk air umpan ketel uap antara lain $\mathrm{pH}$, konduktivitas, kesadahan, kandungan silika, dan kandungan fosfat. Penelitian ini bertujuan untuk mengamati dan menganalisis dari pengambilan sampel air umpan ketel uap sampai analisa laboratorium untuk mendapatkan hasil monitoring suhu, $\mathrm{pH}$, konduktiviti/TDS air secara realtime, Untuk mencapai variabel - variabel tersebut maka terciptalah sistem internet of things untuk monitoring kualitas air secara realtime berbasis mikrokontroler NodeMcu ESP 32, hasil pembacaan data tersebut ditampilkan pada layar oled ssd 1306 0,96" serta dikirimkan ke database cloud firebase yang terintegrasi oleh melalui jaringan internet kemudian dapat dilihat melalui aplikasi android yang diakses melalui smartphone dari jarak jauh. Hasil dari pengujian sistem kemudian dibandingkan dengan alat ukur yang telah terstandarisasi. Dari pengambilan 5 sampel pengujian didapatkan bahwa hasil yang cukup baik dari pengecekan 5 jenis sampel air 4 diantaranya memiliki prosentase eror kurang dari $5 \%$, sedangkan rata-rata prosentase error tertinggi pada saat melakukan pengukuran konduktiviti/TDS air jenis softener water yakni $25,04 \%$.
\end{abstract}

\section{ABSTRACT}

In the oil refining industry sector, water needs are needed as feed water in steam boilers. In this sector water has various functions including to be converted into steam as a turbine player in the generation of electrical energy. Some parameters that are important for steam boiler feed water include $\mathrm{pH}$, conductivity, hardness, silica content, and phosphate content. This study aims to observe and analyze from the sampling of steam boiler feed water to laboratory analysis to obtain the results of temperature monitoring, $\mathrm{pH}$, conductivity / TDS water in real time, To achieve these variables then created an internet of things system for realtime water quality monitoring based on NodeMcu ESP 32 microcontroller, the results of the data reading are displayed on the oled ssd screen $13060.96 "$ As well as being sent to the firebase cloud database integrated by the internet network can then be viewed through android applications accessed via smartphone remotely. The results of the system testing are then compared to standardized measuring instruments. From the collection of 5 test samples, it was found that the results were quite good from checking 5 types of water samples 4 of which had a percentage of errors of less than 5\%, while the average percentage of error was highest when taking conductivity / TDS measurements of water softener water type which is $25.04 \%$.

\section{Korespondensi Penulis:}

Rudi Khaerudin

Program Studi Teknik Elektro

Fakultas Teknik dan Sains Universitas Muhammadiyah Purwokerto

JL. Raya Dukuhwaluh, Purwokerto, 53182

Email: rudikhaerudin1995@gmail.com 


\section{PENDAHULUAN}

Pada sektor industri kebutuhan air ini sangat penting, salah satunya adalah sebagai umpan balik pada boiler ketel uap. Pada sector ini air memiliki berbagai macam fungsi diantaranya untuk menghasilkan uap sebagai pemutar turbin dalam pembangkitan energi listrik. Akan tetapi sebelum digunakan air ini harus diuji terlebih dahulu dengan berbagai parameter antara lain $\mathrm{pH}$. Konduktivitas, kesadahan, kandungan silika, dan kandungan fosfat. Maka dari itu dibuatlah penelitian dengan judul "Perancangan Alat Pendeteksi Kualitas Air Minum Menggunakan Elektrolisis Dan Konduktivitas Berbasis Arduino Uno " dimana Elektrolisis, konduktivitas dan TDS ( Total Disolved Solid ) adalah salah satu parameter dalam menentukan kualitas suatu air minum dengan memanfaatkan daya hantar listrik yang terdapat pada air yang kemudian diolah dalam arduino uno dan ditampilkan hasilnya pada LCD. [3]

Dalam pengukuran kualitas memiliki beberapa kelebihan dimana dalam memonitoring dilakukan secara sederhana dengan menggunakan ATmega 32 yang ditampilkan pada LCD 16x2, akan tetapi pada pengukuran kualitas air hanya memiliki 2 parameter yaitu konduktivitas dan suhu pada air dan sistemnya pun belum menggunakan sistem IoT [2]

Monitoring kualitas keasaman, kekeruhan dan suhu air sangat penting dilakukan untuk mengetahui baik buruknya kualitas air. Pada penelitiannnya mengukur 3 parameter $\mathrm{pH}$, kekeruhan air, dan suhu pada air dan dimonitoring dengan menggunakan thingspeak yang dimana thingspeak ini memiliki update data yang kurang real-time karena data hanya dapat di update setiap 15 detik.[1]

Instalasi pengolahan air limbah (IPAL) dan memonitoring secara realtime berbasis mikrokontroler, sebagai alternatif yang bertujuan untuk meningkatkan kinerja IPAL dengan bantuan mikrokontroler sebagai sistem pengendali, kemudahan dalam pengoperasian dan biaya tidak mahal serta mempermudah dalam pemantauannya melalui teknologi InternetOfThings. [4]

\section{METODE PENELITIAN}

Metode Penelitian yang digunakan yaitu eksperimen dengan mengembangkan deteksi kualitas air berdasarkan suhu, sifat tingkat keasaman dan jumlah zat padat terlarut yang berbasis mikrokontroler NodeMcu ESP 32 dan nantinya akan terintegrasi dengan aplikasi android. Pada pengukuran suhu menggunakan sensor suhu ds $18 \mathrm{~b} 20$. Sensor digital ini memiliki rentang pengukuran suhu $-55^{\circ} \mathrm{C}-150^{\circ} \mathrm{C}$. Untuk pengukuran tingkat keasaman air menggunakan sensor $\mathrm{pH}$ meter E-4502C, untuk jumlah zat padat terlarut menggunakan sensor konduktivitas. Karakterisasi ke tiga sensor yaitu dengan cara memasukan bagian sensor tersebut kedalam larutan agar dapat dilihat seberapa besar nilai keluarannya.Pengambilan data dilakukan dengan menggunakan beberapa sampel air .

Tabel 1. Daftar sampel air larutan pengujian

\begin{tabular}{cc}
\hline NO & Jenis Sampel \\
\hline 1 & Drinking Water \\
2 & Softener Water \\
3 & Blowdown Boiler Water \\
4 & Product Water SWD \\
5 & Cooling Water \\
\hline
\end{tabular}




\subsection{Alur Penelitian}

Alur penelitian dalam melakukan Implementasi IOT untuk monitoring kualitas air secara realtime pada Utilities PT.Kilang Pertamina Internasional Cilacap berbasis mikrokontroler Node MCU ESP32 meliputi kegiatan yang akan dilakukan tertulis seperti pada Gambar 1 :

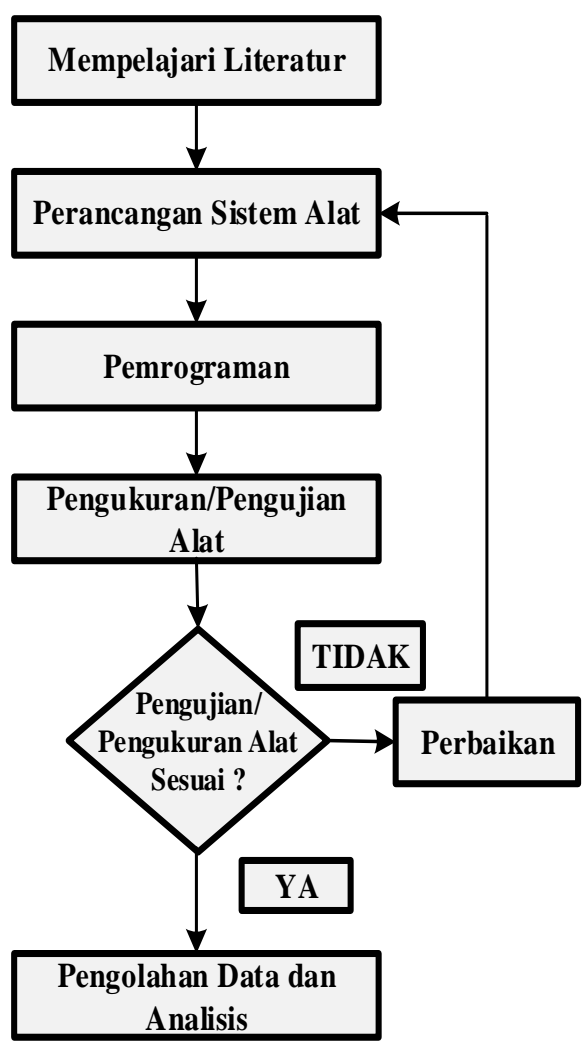

Gambar 1. Alur Penelitan 


\subsection{Flowchart Sistem}

Alat dapat berfungsi dengan baik harus memiliki acuan pada sistemnya dengan menggunakan flowchart sistem. Pada penelitian ini flowchart sistem yang digunakan sebagai berikut 2 .

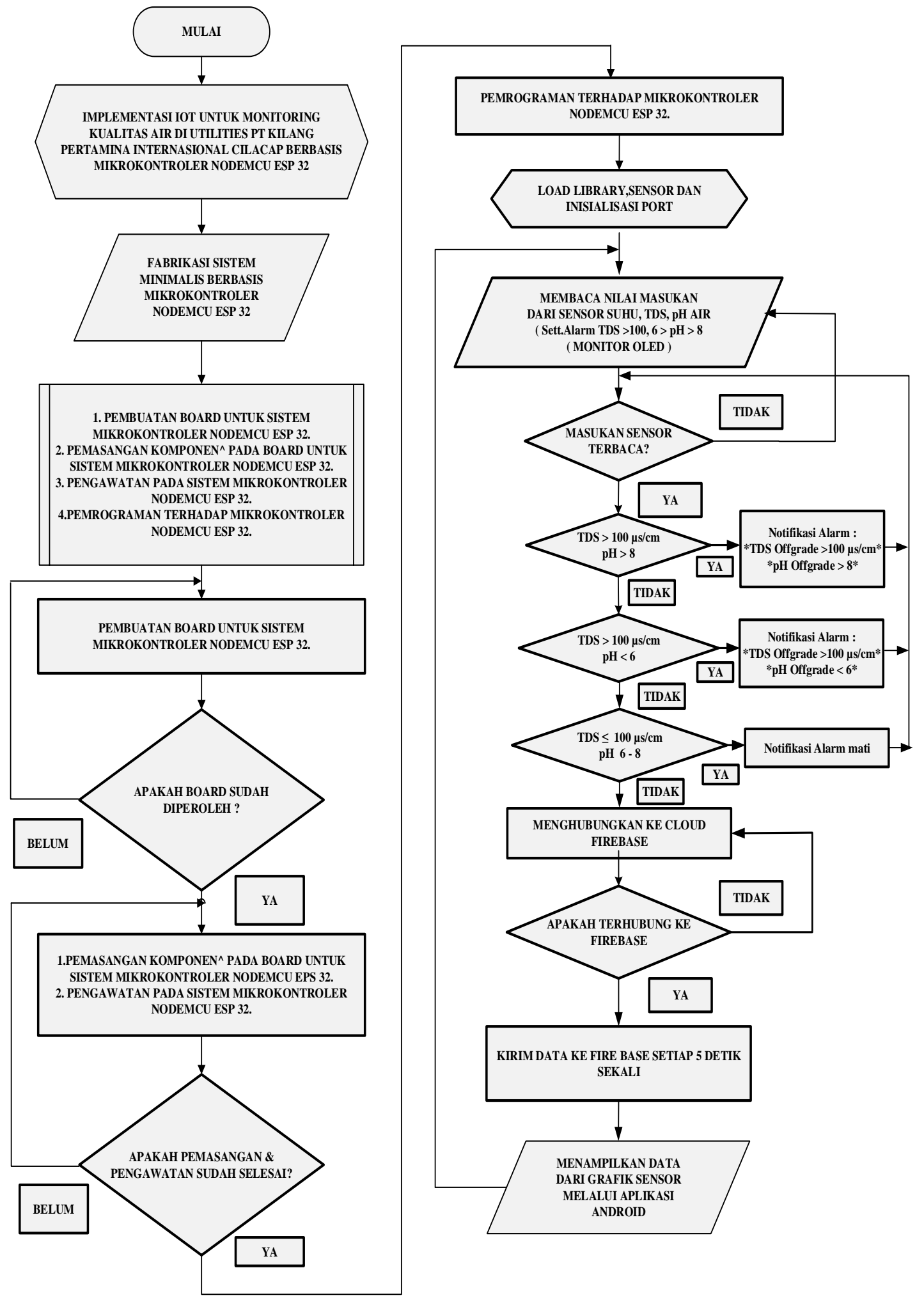

Gambar 2. Flowchart Sistem 


\subsection{Perancangan Perangkat Keras}

Box perangkat berfungsi untuk merapikan setiap komponen pada Alat di desain dengan rapi untuk mempermudah meletakkan sensor pada drip chamber. Seperti Gambar 3. berikut.

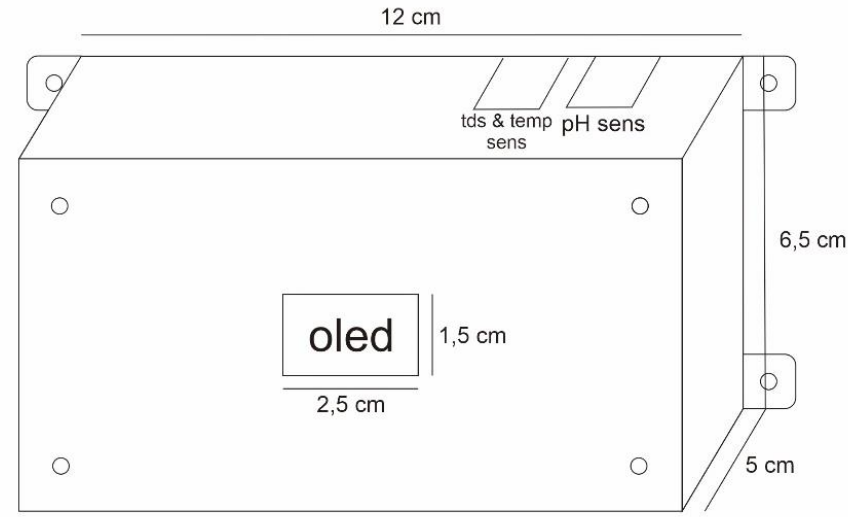

Gambar 3. Desain Box Alat

3. HASIL DAN PEMBAHASAN

Setelah melakukan pengujian rangkaian dan perancangan alat maka diperoleh hasil seperti Gambar 4. dan Gambar 5. Berikut.

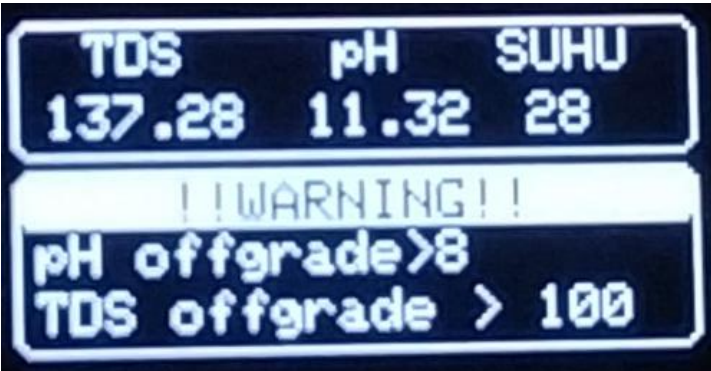

Gambar 4. Tampilan Monitoring Pada Alat

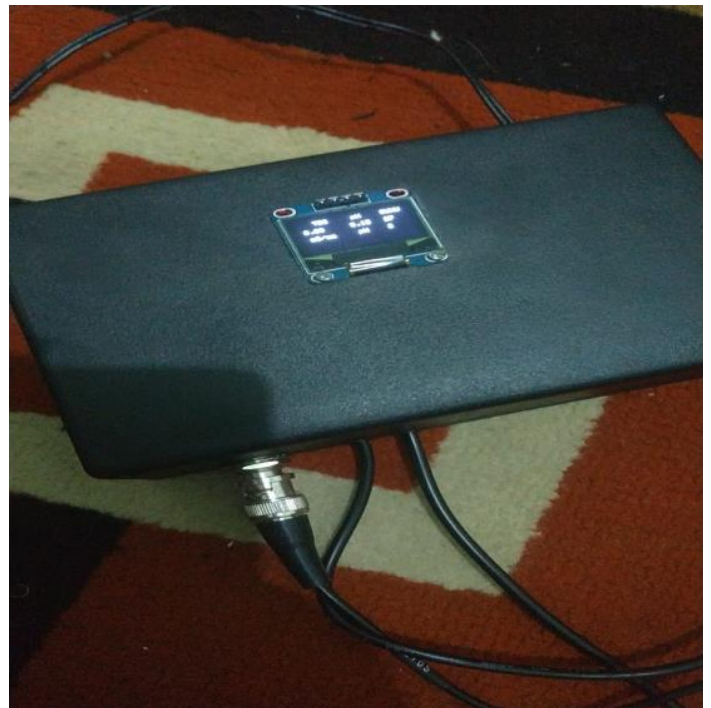

Gambar 5. Bentuk dan Tampilan Alat 


\subsection{Hasil Pengujian Dan Analisa Sistem}

Pada Pembuatan perangkat keras menggunakan beberapa komponen yang disusun sesuai dengan perencanaan yang dibuat oleh penulis, penyusunan komponen dilakukan secara manual dengan menghubungkan antar komponen menggunakan pin kontak yang tersedia pada komponen, Sensor yang digunakan pada saat kalibrasi sebanyak tiga buah yaitu, sensor suhu ds18b20, sensor TDS V 1.0 dan sensor pH E-4502C. Sensor-sensor tersebut nantinya akan diletakan dalam satu kotak yang sudah terintegrasi dengan mikrokontroler NodeMcu ESP 32. Besar kesalahan relatif sensor dihitung dengan menggunakan persamaan berikut.

$$
\operatorname{Error}(\%)=\frac{(P S-P L)}{P L} \times 100 \%
$$

Keterangan persamaan (3.1) :

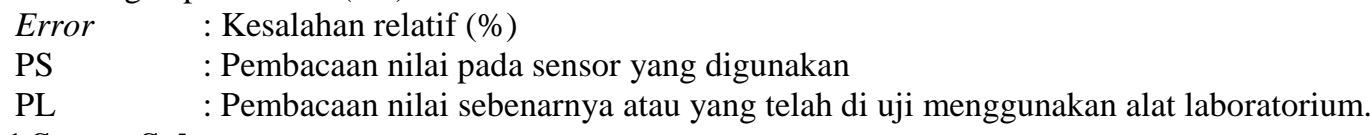

\subsubsection{Sensor Suhu}

Pada karakterisasi sensor suhu ds18b20 dilakukan dengan membandingkan nilai keluaran sensor (nilai digital) dengan nilai pada termometer air merek kurita. Baik keluaran pada sensor maupun pada termometer memiliki satuan celcius $\left({ }^{\circ} \mathrm{C}\right)$. Hasil pengukuran dirangkum pada gambar 6 dan 7 Kesalahan relatif pengukuran dihitung menggunakan persamaan (3.1) sehingga diperoleh grafik pada gambar 3.5 Dari grafik tersebut dapat dilihat bahwa kesalahan relatif pengukuran maksimum yaitu sebesar $6,89 \%$ serta pada gambar 7 dari grafik tersebut dapat dilihat untuk rata-rata kesalahan relative pengukuran maksimum yaitu sebesar $2,75 \%$.

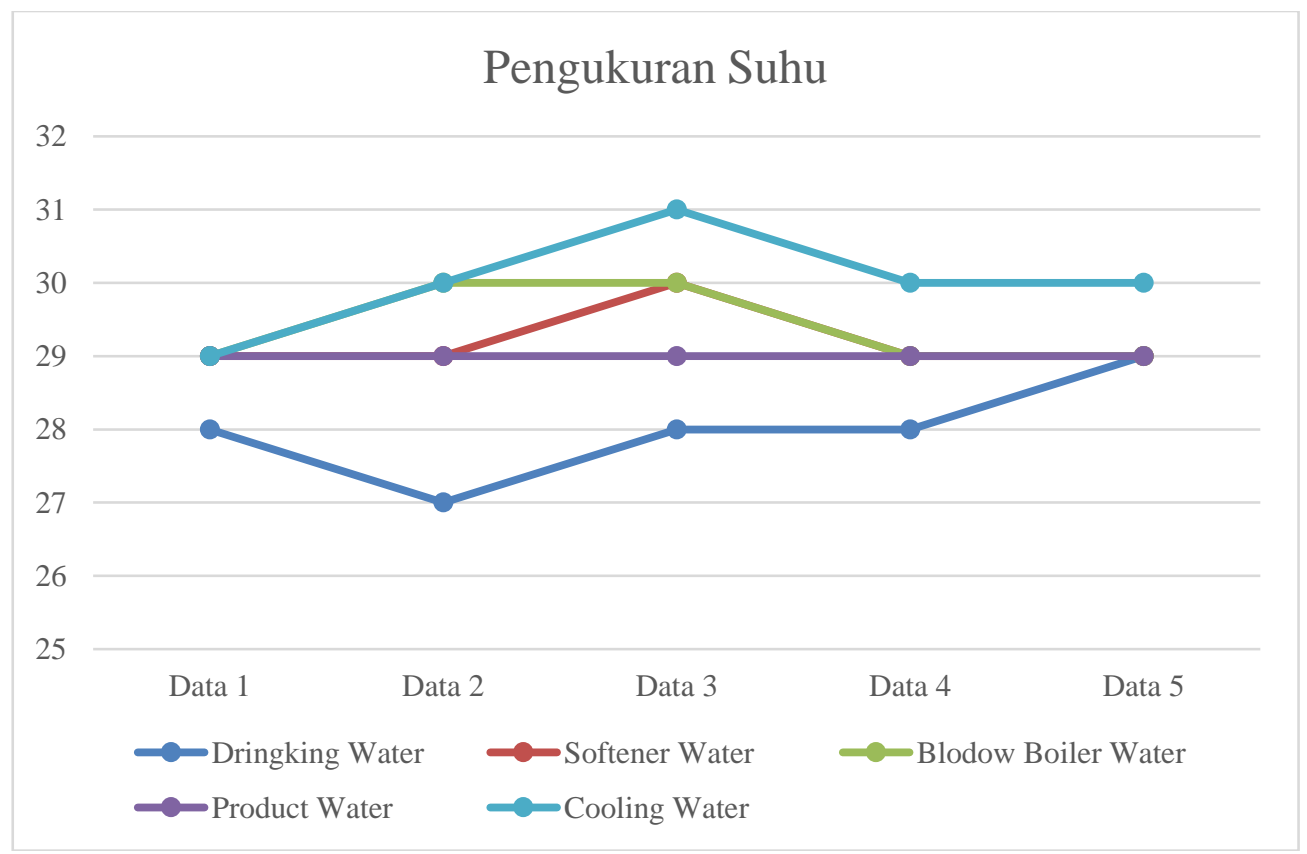

Gambar 6. Grafik pengukuran suhu dengan menggunakan alat 


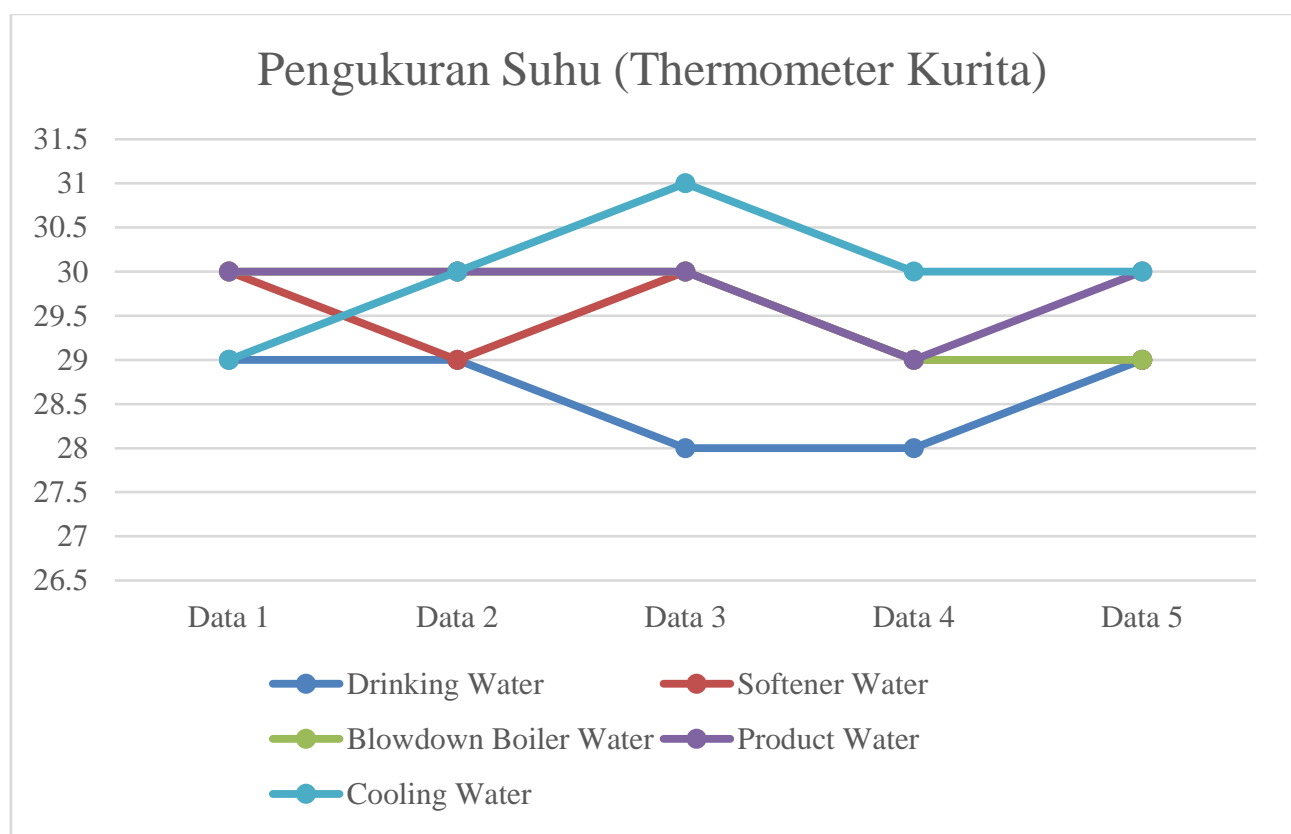

Gambar 7. Grafik Pengukuran suhu dengan menggunakan Thermometer Kurita

Dari grafik pengukuran suhu dengan alat dan dengan pengukuran suhu dengan thermometer kurita terdapat perbedaan data yang tidak begitu tinggi dengan selisih yang tidak begitu banyak. Persen data error yang terjadi ditampilkan pada gambar grafik 8 dan 9

\section{Grafik Kesalahan Relatif Pengukuran Suhu}

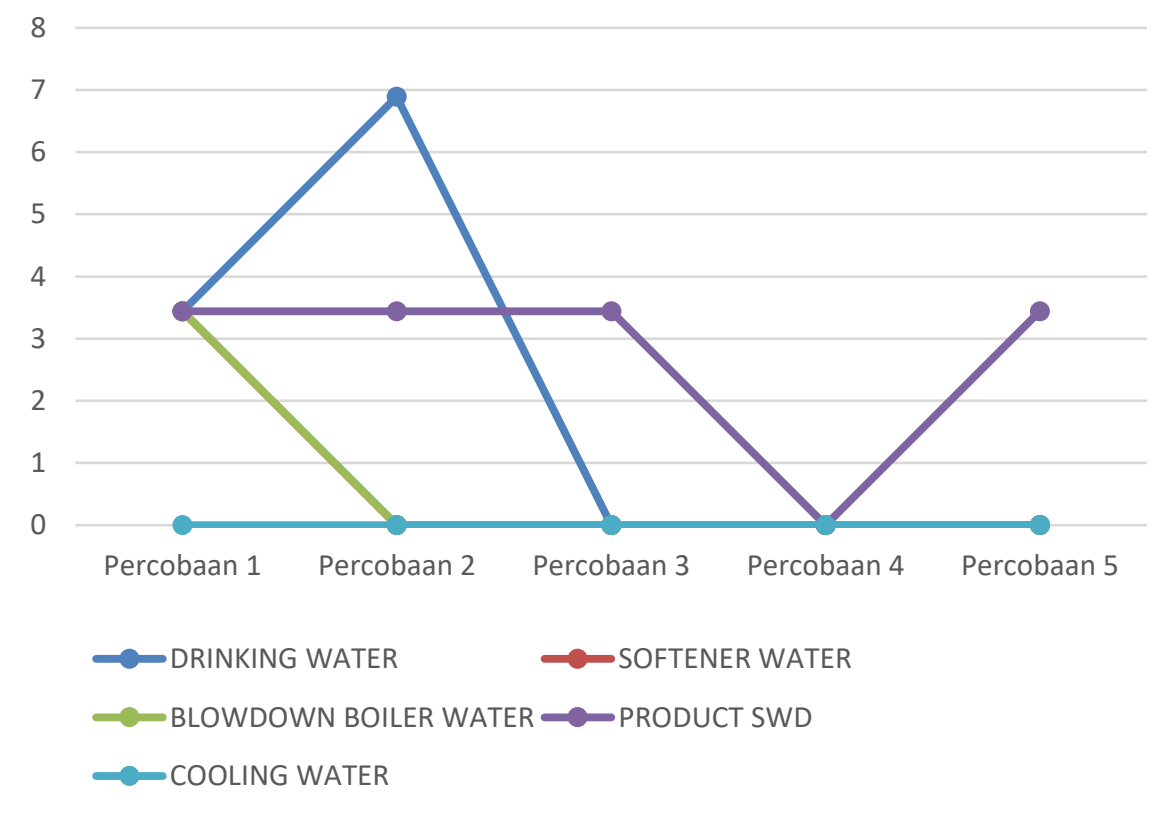

Gambar 8. Grafik hubungan nilai kesalahan relatif terhadap keluaran sensor suhu 


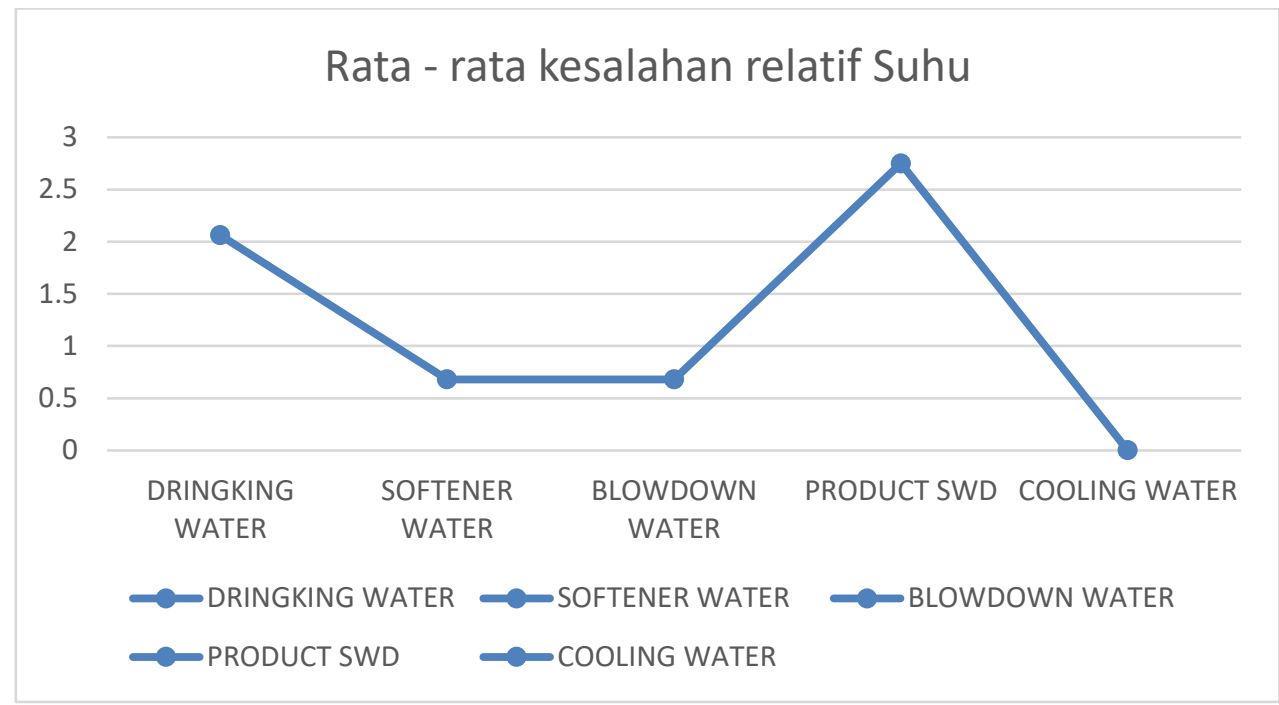

Gambar 9. Grafik hubungan nilai rata-rata kesalahan relatif terhadap keluaran sensor suhu

\subsubsection{Sensor $\mathbf{P h}$}

Untuk mendapatkan nilai $\mathrm{pH}$ dengan sekala $0-14$ perlu dilakukan pengkalibrasian atas besaran tegangan yang dihasilkan oleh sensor $\mathrm{pH}$. Cara pengkalibrasianya dilakukan dengan skala berbandingan antara tegangan dengan larutan yang telah memiliki nilai $\mathrm{pH}$ pasti. Pada proses ini peneliti mengguakan $\mathrm{pH}$ buffer dengan nilai 4,01 sebagai larutan asam dan buffer $\mathrm{pH}$ bernilai $\mathrm{pH}$ 6,86 sebagai larutan netral.

a. Proses Kalibrasi Sensor PH E-4502C

Pada proses kalibrasi sensor untuk mendapatkan niai tegangan $\mathrm{pH}$ dengan menggunakan larutan pH bernilai 4,01 sebagai asam dan 6,86 sebagai netral. Rentang nilai analog yang dihasilkan sensor pH E-4502C sebesar $0-1024$ dan rentang nilai tegangan yang dicari antara $0-5$ volt. Rumus konversi perhitungan yang digunakan adalah :

$$
\text { Tegangan } p H=\text { Analog } x(5.0 / 1024)
$$

Keterangan Persamaan (3.2) :

1. Analog : nilai yang dibaca oleh sensor $\mathrm{pH}$

2. 5.0 : nilai tegangan maksimal yang digunakan pada mikrokontroler

3. 1024 : nilai analog maksimal yang dibaca oleh sensor

\section{Pengukuran $\mathrm{pH}$}

12

10

2

0

Data 1

- Drinking Water

Product Water
Data 2

Data 3

- Softener Water

-Cooling Water

Gambar 10. Grafik pengukuran pH dengan menggunakan alat 


\section{Pengukuran pH (pH Kurita)}

12

10

8

6

4

2

0
Data 1
Data 2
Data 3
Data 4
Data 5

-Drinking Water

- Softener Water

-Blowdown Boiler Water

- Product Water

-Cooling Water

Gambar 11. Grafik Pengukuran pH dengan menggunakan pH Kurita

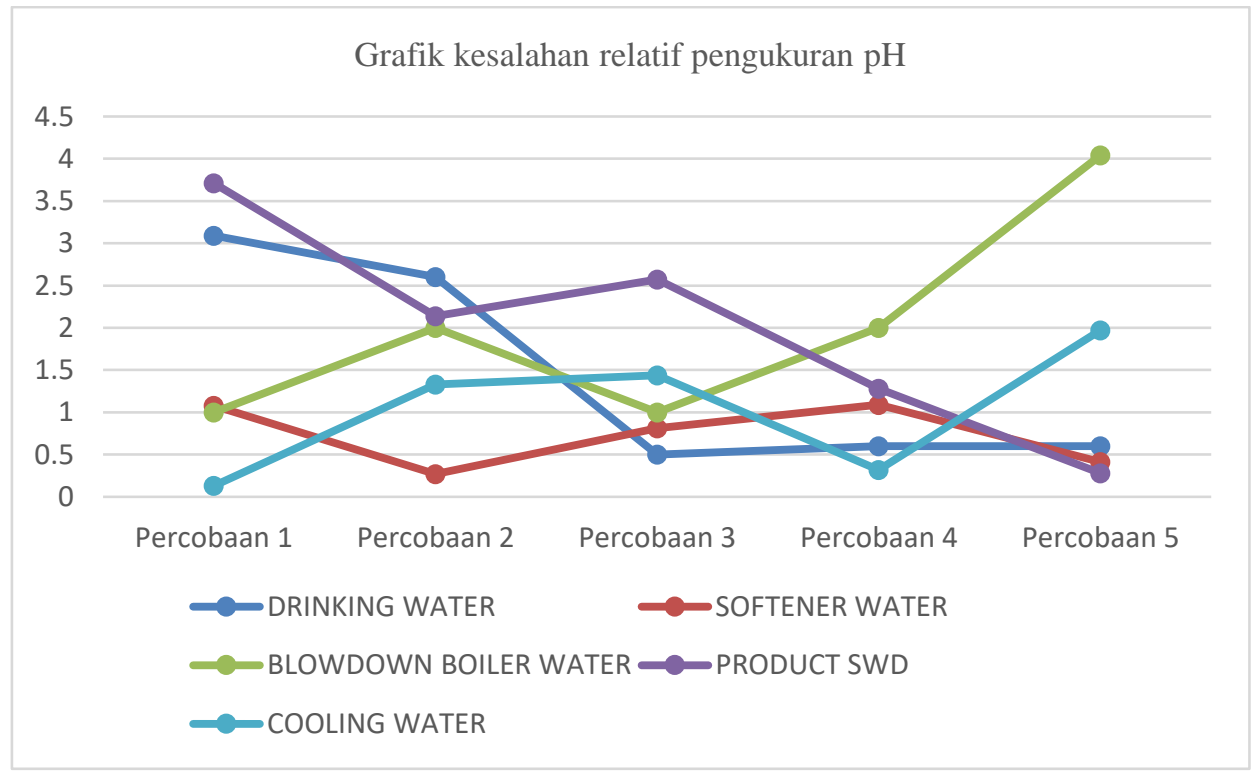

Gambar 12. Grafik hubungan nilai kesalahan relatif terhadap keluaran sensor pH 


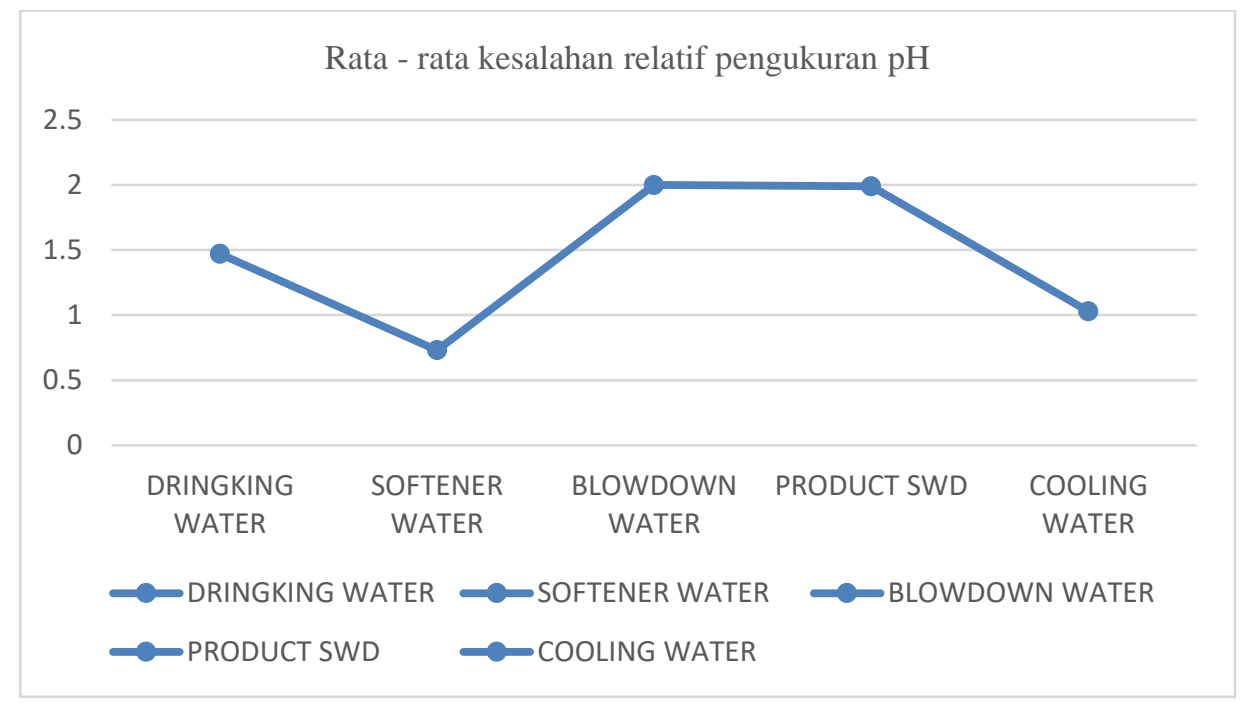

Gambar 13. Grafik hubungan nilai rata-rat kesalahan relatif terhadap keluaran sensor $\mathrm{pH}$

Pada karakterisasi sensor $\mathrm{pH}$ E-4502C dilakukan dengan membandingkan nilai keluaran sensor (nilai digital) dengan nilai pada $\mathrm{pH}$ meter air merek kurita. Baik keluaran pada sensor maupun pada pH meter. Hasil pengukuran dirangkum pada gambar 10. dan 11. Kesalahan relatif pengukuran dihitung menggunakan persamaan (3.1) sehingga diperoleh grafik pada gambar 12. Dari grafik tersebut dapat dilihat bahwa kesalahan relatif pengukuran maksimum yaitu sebesar 4,04 \% serta pada gambar 13. dari grafik tersebut dapat dilihat untuk rata-rata kesalahan relative pengukuran maksimum yaitu sebesar 2,0 \%.

\subsubsection{SENSOR TDS}

Pada karakterisasi sensor TDS V.10 dilakukan dengan membandingkan nilai keluaran sensor (nilai digital) dengan nilai pada Electrical conductivity air merek kurita. Baik keluaran pada sensor maupun pada EC meter. Hasil pengukuran dirangkum pada gambar 14. dan 15. Kesalahan relatif pengukuran dihitung menggunakan persamaan (3.1) sehingga diperoleh grafik pada gambar 16. Dari grafik tersebut dapat dilihat bahwa kesalahan relatif pengukuran maksimum yaitu sebesar 4,04 \% serta pada gambar 17 . dari grafik tersebut dapat dilihat untuk rata-rata kesalahan relative pengukuran maksimum yaitu sebesar $2,0 \%$.

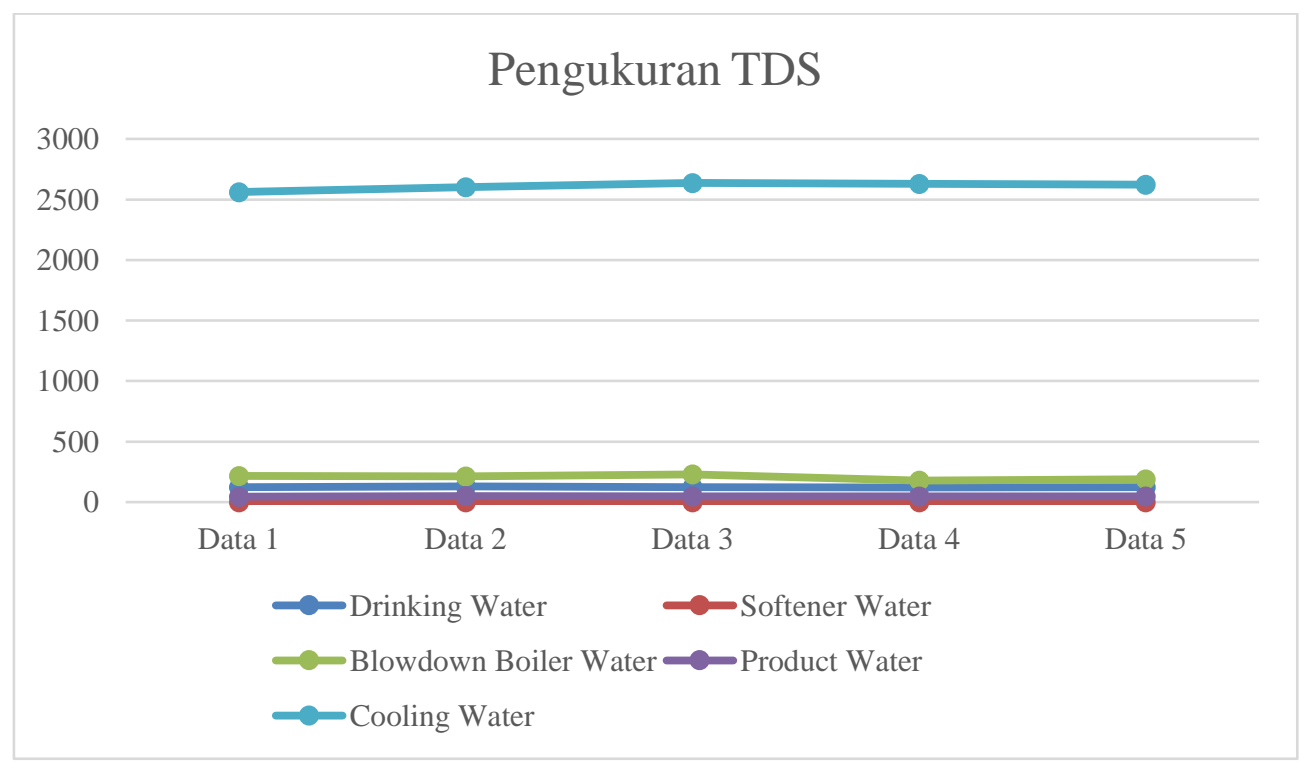

Gambar 14. Grafik pengukuran TDS dengan menggunakan alat 


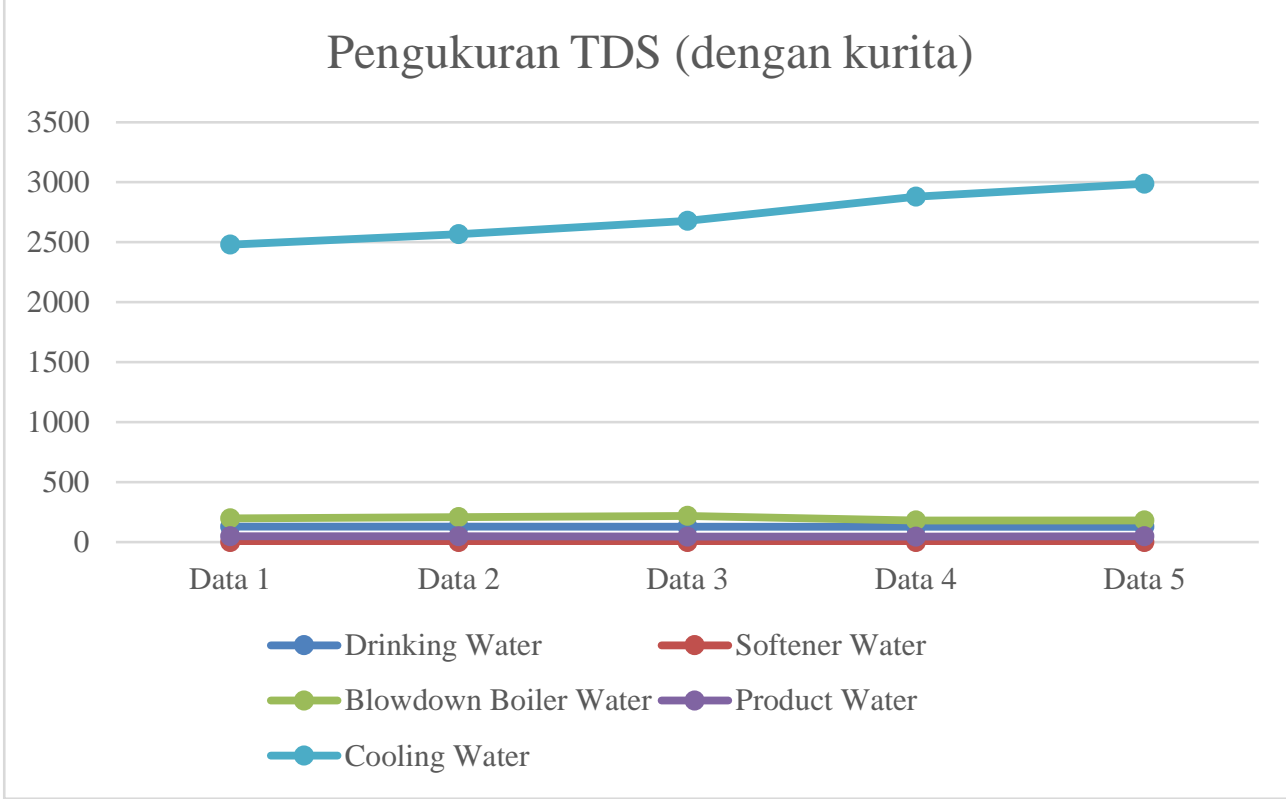

Gambar 15. Grafik pengukuranj TDS dengan menggunakan Kurita

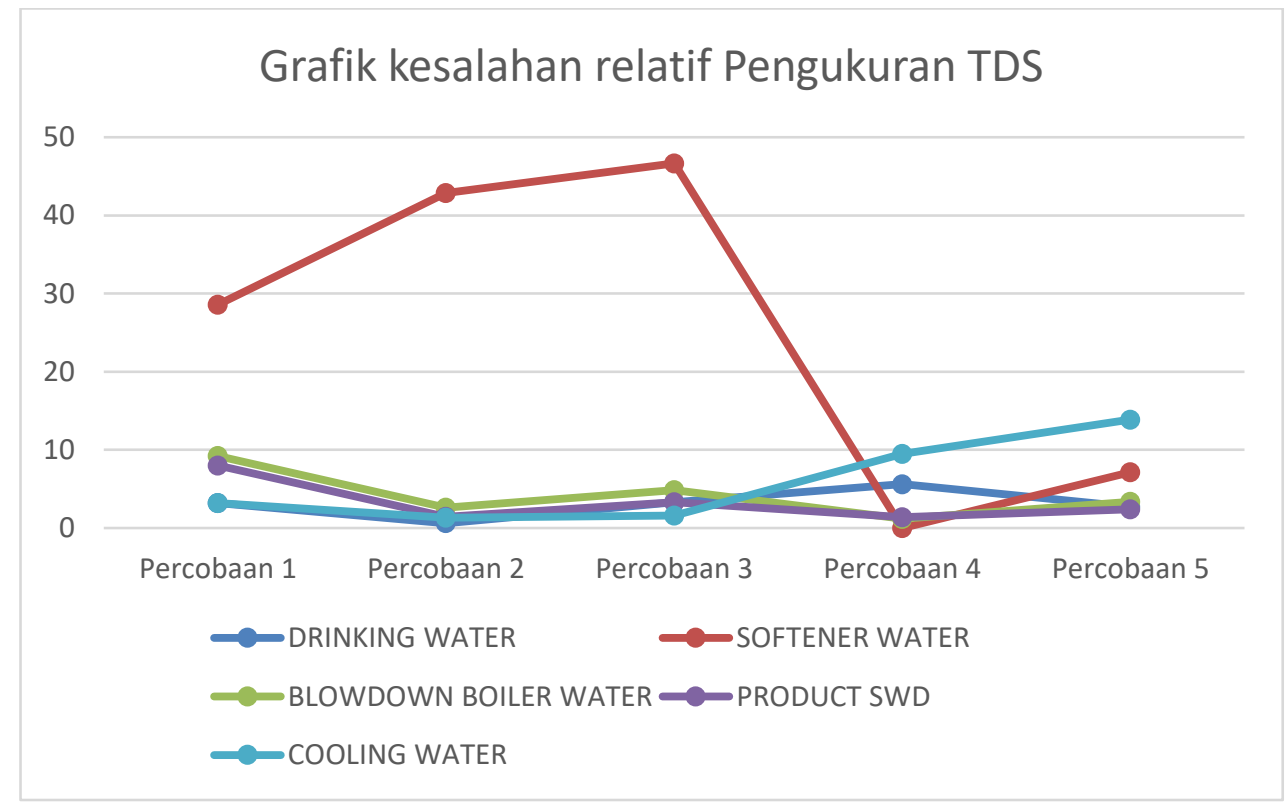

Gambar 16. Grafik hubungan nilai kesalahan relatif terhadap keluaran sensor TDS. 


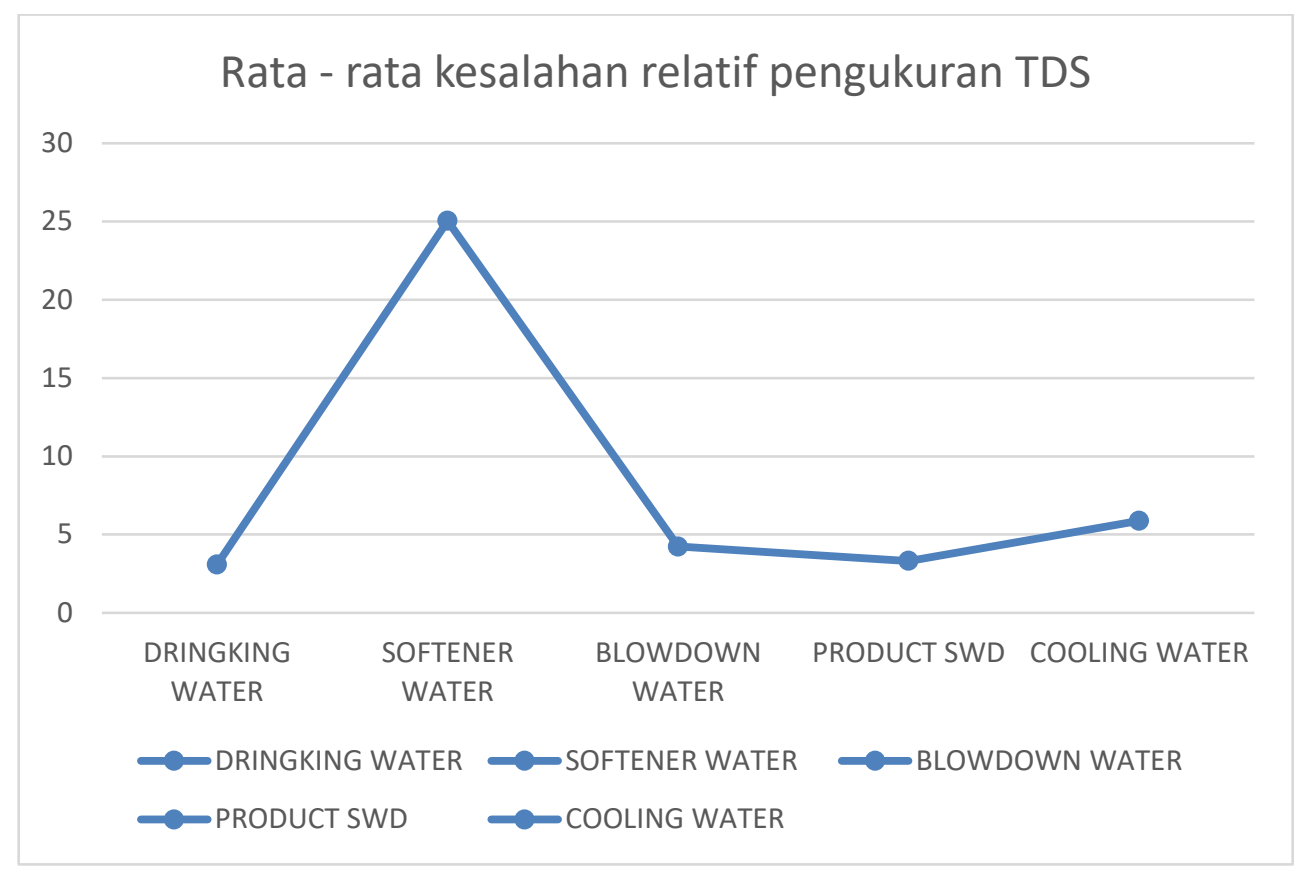

Gambar 17. Grafik hubungan nilai rata-rata kesalahan relatif terhadap keluaran sensor TDS

\section{KESIMPULAN}

Dari hasil pengujian alat sensor suhu yang terukur dapat bekerja sesuai yang diharapkan dan memiliki pembacaan temperatur air yang cukup akurat dengan keselisihan antara data pengukuran asli dengan data pembacaan sensor pada thermometer kurita memiliki selisih yang terbilang kecil. Pada hasil pengujian sensor $\mathrm{pH}$ air, sensor dapat bekerja dengan baik hanya saja dalam pembacaan menggunakan dengan pembacaan sensor pada kurita terdapat selisih pembacaan yang cukup berbeda dikarenakan pembacaan sensor $\mathrm{pH}$ meter yang sangat sensitive dengan level \& temperature sampel.

Pada pengujian sensor TDS menghasilkan bahwa untuk mengetahui nilai TDS / EC air dapat bekerja dengan baik hanya saja dalam pembacaan data menggunakan alat dengan pembacaan sensor menggunakan kurita terdapat cukup banyak selisih pembacaan dikarenakan pembacaan sensor TDS meter yang sangat sensitive dengan level \& temperature sampel serta pembacaan nya masih dalam satuan ppm sedangkan alat pembanding yang terstandart satuannya micro siemens.

Hasil pengujian aplikasi Android, sistem aplikasi pada android dapat bekerja dengan baik, apabila terdapat pembacaan data parameter temperature, $\mathrm{pH}$, dan TDS air, data dapat ditampilkan secara realtime pada layar oled dan aplikasi android.Dari keseluruhan pengujian yang telah dilakukan terdapat nilai rata - rata error yang cukup tinggi pada pengukuran nilai kualitas air pada sample softener water yang dimana nilai rata - rata total error sebesar 25,04 \% hal ini terjadi karena pada pembacaan nilai kualitas air yang cukup rendah sehingga terdapat perbedaan data yang cukup besar ketika dimasukkan kedalam rumus untuk menentukan persentase error. Sedangkan rata - rata error pada pengukuran $\mathrm{pH}$, suhu, dan TDS / EC pada sample air yang lain memiliki nilai rata - rata error dibawah $5 \%$ sehingga dapat disimpulkan bahwa hasil dari pengujian alat ini memiliki nilai error yang cukup rendah yaitu dibawah $5 \%$

\section{DAFTAR PUSTAKA}

[1] Akbar,Son Ali, Kalbuadi ,dan Yudhana,anton.2019.Online monitoring kualitas air waduk berbasis thinkspeak.ejournal Undip,Vol. 21 : 109-115.

[2] Effendi,Ruslan, Arief Goeritno, Rakhmad Yatim.2015.Prototipe sistem pendeteksian awal pencemaran air berbantuan sensor konduktivitas dan suhu berbasis mikrokontroler. Jurnal Semnastek, Volume 017 (2407 - 1846):17.

[3] Maulana, Inan. (2017). Perancangan alat pendeteksi kualitas air minum menggunakan elektrolisis dan konduktivitas berbasis arduino uno.Skripsi. Universitas Negeri Yogyakarta.

[4] Hafiidhudin.(2018).Prototipe sistem otomatisasi instalasi pengolahan air limbah (IPAL) dan monitoring secara realtime berbasis mikrokontroller.Skripsi.Universitas Pakuan

[5] Irfan,Fadhilah,dan Afdal.(2016).Analisis Hubungan Konduktivitas Listrik dengan Total Dissolved Solid (TDS) dan Temperatur pada Beberapa Jenis Air. Jurnal Fisika Unand, Volume 5(1):85-93. 
[6] Khairunnas,dan Mulya Gusman.(2015). Analisis Pengaruh Parameter Konduktivitas, Resistivitas dan TDS Terhadap Salinitas Air Tanah Dangkal pada Kondisi Air Laut Pasang dan Air Laut Surut di Daerah Pesisir Pantai Kota Padang. Jurnal Bina Tambang, Volume 3(4):1751-1760.

[7] Krisdan,Agustinus Satrio.2019. Rancang bangun sistem pengontrol salinitas air otomatis berbasis arduino uno dengan mengggunakan sensor konduktivitas di pt. Citra larva cemerlang. Skripsi. Universitas Lampung.

[8] Partuti,Tri.2014. Efektivitas resin penukar kation untuk menurunkan kadar total dissolved solid (tds) dalam limbah air terproduksi industri migas. Jurnal Integrasi Proses Vol. 5(1):1-7.

[9] Utomo,Margo,dan Suryono.2016.Rancang bangun sistem monitoring konduktivitas listrik air menggunakan wireless sesnor system (wss). Youngster Physics Journal Volume 5(4):219-226.

[10] Zamora,Ronaldi,Harmadi,dan Wildan.2015. Perancangan alat ukur tds (total dissolved solid) air dengan sensor konduktivitas secara real time. Jurnal Sainstek Vol. VII(1): 11-15. 
